\title{
Lower Piston Bearing Device
}

National Cancer Institute

\section{Source}

National Cancer Institute. Lower Piston Bearing Device. NCI Thesaurus. Code C50038.

A bearing located toward the bottom of a piston. 